\title{
KAJIAN SEMIOTIKA DALAM FILM
}

\author{
Yoyon Mudjiono \\ Dosen Tetap Program Studi IImu Komunikasi Fakultas Dakwah IAIN Sunan \\ Ampel Surabaya
}

\begin{abstract}
Abstraksi
Film memiliki nilai seni tersendiri, karena film tercipta sebagai sebuah karya dari tenaga-tenaga kreatif yang profesional di bidangnya. Film sebagai benda seni sebaiknya dinilai dengan secara artistik bukan rasional. Studi perfilman boleh dikatakan bidang studi yang relatif baru dan tidak sebanding dengan proses evolusi teknologinya. Semiotika merupakan suatu studi ilmu atau metode analisis untuk mengkaji tanda dalam suatu konteks skenario, gambar, teks, dan adegan di film menjadi sesuatu yang dapat dimaknai. Memaknai berarti bahwa obyek-obyek tidak hanya membawa informasi, dalam hal ini obyek-obyek itu hendak berkomunikasi, tetapi juga mengkonstitusi sistem terstruktur dari tanda yang digunakan dalam film tersebut.
\end{abstract}

Kata Kunci: Semiotika, Film

\section{Pendahuluan}

Setiap bentuk kesenian, seperti seni musik, seni tari, seni sastra, seni rupa maupun seni peran memerlukan apresiasi dari penikmatnya masing-masing. Secara harfiah, apresiasi seni berarti penghargaan terhadap kehadiran sebuah karya seni. Karya seni mengalami perkembangan dari tahun ke tahun, hingga pada akhirnya tercipta perpaduan yang seimbang dan harmonis antara seni sastra, seni musik,seni peran dan komedi yang dikemas dalam bentuk film. Film merupakan sarana baru yang digunakan untuk menyebarkan hiburan yang sudah menjadi kebiasaan terdahulu, serta menyajikan cerita, peristiwa, musik, drama, lawak dan sajian teknis lainnya kepada masyarakat umum.

Studi perfilman boleh dikatakan bidang studi yang relatif baru dan tidak sebanding dengan proses evolusi teknologinya. Exploitasi studi perfilman yang pernah terjadi pada dekade 60-70 an di Eropa dan Amerika ternyata tidak banyak membawa perubahan yang berarti. Hasrat untuk menghasilkan suatu pendekatan yang holistik dalam studi perfilman yang bersifat multidisipliner dan interdisipliner nampaknya masih berupa angan-angan. Tak terkecuali bila studi perfilman dilihat dalam konteks Ilmu Komunikasi. Meski film merupakan bagian 
integral dalam bidang Ilmu Komunikasi, ternyata kesan "penganak-tirian" terhadap studi film memang harus diakui. Studi film masih kurang memperoleh perhatian yang memadai di kalangan para ilmuwan komunikasi. Ini terbukti langkanya bahan-bahan acuan yang secara khusus mengupas studi perfilman secara umum apalagi yang berkaitan dengan konteks Ilmu Komunikasi ${ }^{1}$

Film memiliki nilai seni tersendiri, karena film tercipta sebagai sebuah karya dari tenaga-tenaga kreatif yang profesional di bidangnya. Film sebagai benda seni sebaiknya dinilai dengan secara artistik bukan rasional. Mengapa film tetap ditonton orang? Film bukan hal baru lagi masyarakat. Alasan umum, film berarti bagian dari kehidupan modern dan tersedia dalam berbagai wujud, seperti di bioskop, tayangan dalam televisi, dalam bentuk kaset video, dan piringan laser (laser disc). Film bukan hanya menyajikan pengalaman yang mengasyikkan, melainkan juga pengalaman hidup sehari-hari yang dikemas secara menarik.

Alasan alasan khusus mengapa seseorang menyukai film, karena ada unsurnya dalam usaha manusia untuk mencari hiburan dan meluangkan waktu, karena film tampak hidup dan memikat, menonton film dapat dijadikan bagian dari acara-acara kencan antara pria dan wanita. Hal ini merupakan sasaran utama bagi pembuatan film untuk dapat menghasilkan produksi film yang dikemas dalam cerita-cerita yang menarik, dan memasukkan nilai-nilai yang dapat memperkaya batin untuk disuguhkan kepada masyarakat sebagai cerminan kepada hal-hal di dunia ini dengan pemahaman baru. Karena itu film dianggap sebagai suatu wadah pengekspresian dan gambaran tentang kehidupan sehari-hari.

Sutradara Richard Buntario mengatakan "layar lebar sendiri merupakan industri baru, mau enggak mau harus dibuat sebuah komunitas baru. Nah, komunitas ini sendiri sangat penting buat masa ke depannya. Siapa pun, entah praktisi film, harus berfikir captive market. Jadi jelas segmennya siapa yang mau diincar" ${ }^{\prime 2}$.

Kehadiran film merupakan respon terhadap "penemuan" waktu luang di luar jam kerja dan jawaban terhadap kebutuhan menikmati unsur budaya yang sebelumnya telah dinikmati oleh orang-orang yang berbeda di"atas" mereka. Dengan demikian jika ditinjau dari segi perkembangan fenomenalnya, akan terbukti bahwa peran yang dimainkan oleh film dalam memenuhi kebutuhan tersembunyi memang sangat besar ${ }^{3}$.

\footnotetext{
1 Budi Irwanto, Film, Ideologi, dan Militer; Hegemoni Militer dalam Sinema Indonesia, (Yogyakarta: Media Pressindo, 1999), hal. 5.

2 Buntario, Richard, Kompas, Edisi Jumat, 19 September 2003

${ }^{3}$ www.kompas.com
} 
Dalam seni peran, bahasa memang menjadi unsur utamanya. Dalam Ilmu Komunikasi dinyatakan bahwa proses komunikasi secara primer adalah proses penyampaian pikiran atau perasaan seseorang kepada orang lain dengan menggunakan lambang (simbol) sebagai media. Lambang sebagai media primer dalam proses komunikasi adalah bahasa, isyarat, gambar, dan lain sebagainya yang secara langsung mampu menterjemahkan pikiran dan perasaan komunikator kepada komunikasn. Bahwa bahasa yang paling banyak digunakan dalam komunikasi adalah jelas karena hanyalah bahasa yang mampu menterjemahkan pikiran seseorang kepada orang lain. Apakah itu yang berbentuk ide, informasi atau opini, baik mengenai hal yang berbentuk konkret maupun abstrak ${ }^{4}$

Kata atau bahasa, di dalam wahana linguistik, diberi pengertian sebagai sistem simbol bunyi bermakna dan beraktualisasi, yang bersifat abritrer (berubah-rubah) dan konvensional, yang dipakai sebagai alat berkomunikasi oleh sekelompok manusia untuk melahirkan perasaan dan pikiran. Bahasa adalah kombinasi kata yang diatur secara sistematis, sehingga bisa digunakan sebagai alat komunikasi. Kata itu sendiri,merupakan bagian integral dari simbol yang dipakai oleh kelompok masyarakat ${ }^{5}$. Pertama-tama adalah tentu akan sulit membayangkan sesuatu yang tidak terbuka terhadap berbagai interpretasi dan kegunaan, akan sangat sulit menemukan makna yang dimaksudkan. Simbolsimbol dapat memberikan arti makna yang lain bagi orang lain pula, dan bahkan dapat mempunyai arti berbeda-beda bagi orang yang sama. Pada waktu yang berbeda atau keadaan yang berbeda sebuah teks dapat diinterpretasi oleh orang yang sama secara berbeda.

Dalam proses komunikasi makna bukan hanya dikenakan pada obyekobyek luar. Aktivitas interpretasi juga merupakan suatu proses penemuan diri dan pengertian setiap interpretasi terhadap sebuah simbol merupakan suatu interpretasi dan transformasi diri yang di imajinasikan. Makna tak pernah terjadi begitu saja, sebab membuat bermakna merupakan suatu aktivitas yang makan waktu. Dengan demikian pembentukan makna merupakan sesuatu yang kreatif, meluas, dan amat subyektif. Jadi makna itu beraneka ragam dan variatif.

Dalam prakteknya komunikasi merupakan proses penyampaian pesan dalam bentuk lambang bermakna sebagai paduan pikiran dan perasaan berupa ide, informasi, kepercayaan, harapan, himbauan dan sebagainya, yang dilakukan seseorang kepada orang lain, baik langsung secara tatap muka maupun tak langsung melalui media, dengan tujuan mengubah sikap, pandangan atau

\footnotetext{
${ }^{4}$ Onong Uchjana Effendi, Ilmu,Teori dan Filsafat Komunikasi, (Bandung: Citra Adidtya, 1994), hal. 11.

${ }^{5}$ www.google.com
}

Jurnal Ilmu Komunikasi, Vol. 1, No.1, April 2011

ISSN: 2088-981X 
perilaku ${ }^{6}$. Simbol (lambang) bermakna dioperasikan dalam proses komunikasi antar partisipan. Jika antara partisipan terdapat kesesuaian pemahaman tentang simbol-simbol tersebut, tercapai suatu keadaan yang bersifat komunikatif. Dalam proses ini, simbol-simbol yang digunakan oleh partisipan terdiri dari simbol-simbol yag digunakan oleh para partisipan komunikasi baik verbal (bahasa lisan maupun tulisan) dan non verbal (gerak anggota tubuh, gambar, warna dan berbagai isyarat yang tidak termasuk kata-kata atau bahasa). Sebagai simbol non verbal, gambar dapat dipergunakan untuk menyatakan pikiran atau perasaan $^{7}$.

Sebagaimana telah diketahui bahwa ilmu yang mengulas tentang tandatanda adalah semiotika. Lalu, bagaimana bidang terapan semiotika pada komunukasi? Film, musik, komunikasi periklanan, pemberitaan media massa, komik, kartun, sampai kepada tanda-tanda non verbal. Film umumnya dibangun dengan banyak tanda. Tanda-tanda itu termasuk berbagai sistem tanda yang bekerja sama dengan baik dalam upaya mencapai efek yang diharapkan. Hal paling penting dalam film adalah gambar dan suara; kata yang diucapkan (ditambah dengan suara-suara lain yang serentak mengiringi gambar-gambar) dan musik film. Sistem semiotika yang lebih penting lagi dalam film adalah digunakannya tanda-tanda ikonis, yakni tanda-tanda yang menggambarkan sesuatu. Tanda-tanda ikonis yang digunakan dalam film mengisyaratkan pesan kepada penonton, dan setiap isyarat yang diterima akan berbeda, namun apabila cerita yang diperankan memang sudah membentuk satu pokok makna,dalam hal ini makna cerita yang ditampilkan.

\section{Pengertian Semiotika Dalam Film}

Kata semiotika di samping kata semiologi sampai saat ini masih sering dipakai. Selain istilah semiotika dalam sejarah linguistik ada pula digunakan istilah lain seperti semasiologi, sememik, dan semik untuk merujuk pada bidang studi yang mempelajari makna atau arti dari sauatu tanda atau lambang. Menurut Segers dalam (Sobur: 2003) dikatakan bahwa pembahasan yang luas tentang bidang studi yang disebut semiotika telah muncul di negara-negara Anglo-Saxon. Semiologi disebut juga berfikir tentang Saussurean. Dalam penerbitan-penerbitan Prancis, istilah-istilah semiologi kerap sekali dipakai ${ }^{8}$. Sedangkan semiotik digunakan dalam kaitannya dengan karya Charles Sanders Peirce dan Charles Morris. Baik semiotika maupun semiologi, keduanya kurang

\footnotetext{
${ }^{6}$ Op-cit, hal. 60

${ }^{7}$ www.google.com

${ }^{8}$ Alex Sobur, , Semiotika Komunikasi, (Bandung: PT Remaja Rosydakarya, 2003), hal. 12
} 
lebih dapat saling menggantikan karena sama-sama digunakan untuk mengacu kepada ilmu tentang tanda.

Dalam definisi Saussure (Sobur: 2003), semiologi merupakan "sebuah yang mengkaji kehidupan tanda-tanda di tengah masyarakat" dan dengan demikian menjadi bagian dari disiplin psikologi sosial. Tujuannya adalah untuk menunjukkan bagaimana terbentuknya tanda-tanda beserta kaidah-kaidah yang mengaturnya. Sementara istilah semiotika, yang dimunculkan pada akhir abad 19 oleh filsuf aliran pragmatik Amerika Charles Sander Peirce, merujuk kepada "doktrin formal tentang tanda-tanda". Yang menjadi dasar semiotika adalah konsep tentang tanda: tak hanya bahasa dan sistem komunikasi yang tersusun oleh tanda-tanda, melainkan dunia itu sendiri pun-sejauh terkait dengan pikiran manusia-seluruhnya terdiri atas tanda-tanda, karena jika tidak begitu, manusia tidak akan bisa menjalin hubungannya dengan realitas ${ }^{9}$.

Semiotika merupakan suatu studi ilmu atau metode analysis untuk mengkaji tanda dalam suatu konteks skenario, gambar, teks, dan adegan di film menjadi sesuatu yang dapat dimaknai. Sedangkan, kata "semiotika" itu sendiri berasal dari bahasa Yunani, semeion yang berarti "tanda" atau seme ,yang berarti "penafsir tanda". Semiotika berakar dari studi klasik dan skolastik atas seni logika, retorika, dan etika ${ }^{10}$

Tanda-tanda adalah perangkat yang kita pakai dalam upaya mencari jalan di dunia, di tengah-tengah manusia, dan bersama-sama manusia. Semiotika, atau dalam istilah Barthes, semiologi, pada dasarnya hendak mempelajari bagaimana kemanusiaan (humanity) memaknai hal-hal (things). Memaknai (to signify) dalam hal ini tidak dapat dicampuradukkan dengan mengkomunikasikan (to communicate). Memaknai berarti bahwa obyek-obyek tidak hanya membawa informasi, dalam hal ini obyek-obyek itu hendak berkomunikasi, tetapi juga mengkonstitusi sistem terstruktur dari tanda (Barthes, 1988; 179 dalam Kurniawan, 2001) ${ }^{11}$. Tanda-tanda (signs) adalah basis dari seluruh komunikasi. Suatu tanda menandakan sesuatu selain dirinya sendiri,dan makna (meaning) ialah hubungan antara suatu obyek atau idea dan suatu tanda ${ }^{12}$

Charles Sanders Pierce terkenal dengan teori tandanya. Berdasarkan obyeknya, Pierce membagi tanda atas icon (ikon), indekx (indeks), dan symbol (simbol). Ikon adalah tanda yang hubungan antara penanda dan petandanya bersifat bersamaan bentuk alamiah. Atau dengan kata lain,ikon adalah

\footnotetext{
${ }^{9}$ Ibid, hal. 12

${ }^{10}$ Kurniawan, 2001, Semiologi Roland Barthes, (Magelang: Yayasan Indonesiatera, 2001), hal. 49

${ }^{11}$ Ibid, hal. 53

12 Stephen W Littlejohn 1996, Theories of Human Communication, (5 ${ }^{\text {th }}$ Edn; New Mexico: Wadsworth Publishing Company Albuquerque), p. 64
} 
hubungan antara tanda dan obyek atau acuan yang bersifat kemiripan, misalnya,potret dan peta. Indeks adalah tanda yang menunjukkan adanya hubungan alamiah antara tanda dan petanda yang bersifat kausal atau hubungan sebab akibat, atau tanda yang langsung mengacu pada kenyataan. Simbol adalah tanda yang menunjukkan hubungan alamiah antara penanda dan petandanya, hubungan diantaranya bersifat arbitrer atau semena, hubungan berdasarkan konvensi (perjanjian) masyarakat ${ }^{13}$.

Teori Saussure adalah prinsip yang mengatakan bahwa bahasa itu adalah sistem tanda, dan setiap tanda itu tersusun atas dua bagian, yakni signifier (penanda) dan signified (petanda). Menurut Saussure, bahasa merupakan suatu sistem tanda, dan setiap tanda kebahasaan, menurutnya pada dasarnya menyatakan sebuah konsep dan suatu citra suara (sound image), bukan menyatakan sesuatu dengan sebuah nama. Suara yang muncul dari sebuah kata yang diucapkan merupakan penanda (signifer), sedang konsepnya adalah petanda (signified) ${ }^{14}$. Dua unsur tersebut tidak dapat dipisahkan sama sekali. Jika hal itu terjadi maka akan menghancurkan kata itu sendiri.

Sementara itu Barthes melihat signifikasi sebagai sebuah proses yang total dengan suatu susunan yang sudah terstruktur. Signifikasi itu itu tak terbatas pada bahasa,tetapi terdapat pula pada hal-hal yang bukan bahasa. Pada akhirnya Barthes menanggap kehidupan sosial sendiri merupakan suatu bentuk dari signifikasi. Dengan kata lain, kehidupan sosial, apapun bentuknya, merupakan suatu sistem tanda tersendiri pula ${ }^{15}$. Kehidupan sosial seringkali digambarkan dalam tayangan film. Dengan demikian simbol yang tersirat dalam film dapat ditransfer oleh penonton ke dalam kehidupannya.

Hal-hal yang memiliki arti simbolis tak terhitung jumlahnya. Dalam kebanyakan film setting, memiliki arti simbolik yang penting sekali, karena tokoh-tokoh sering dipergunakan secara simbolik. Dalam setiap bentuk cerita, sebuah simbol adalah sesuatu yang kongkret (sebuah obyek khusus, citra, pribadi, bunyi, kejadian atau tempat) yang mewakili atau melambangkan suatu kompleks, ide, sikap-sikap, atau rasa sehingga memperoleh arti yang lebih besar dari yang tersimpan dalam dirinya sendiri. Oleh karena itu sebuah simbol adalah suatu macam satuan komunikasi yang memiliki beban yang khusus sifatnya.

Pada awalnya film adalah hiburan bagi kelas bawah, dengan cepat film mampu menembus batas-batas kelas dan menjangkau kelas lebih luas. Kemampuan film menjangkau banyak segmen sosial, kemudian menyadarkan para ahli komunikasi terutama, bahwa film memiliki potensi untuk mempengaruhi khalayaknya. Karena itu, mulailah merebak studi yang ingin

\footnotetext{
${ }^{13}$ Sobur, Op-cit, hal. 41-42

${ }^{14}$ Ibid, p. 47

${ }^{15}$ Kurniawan, Op.Cit, hal. 53
}

Jurnal Ilmu Komunikasi, Vol. 1, No.1, April 2011

ISSN: 2088-981X 
mengetahui dampak film terhadap masyarakat. Hal ini terlihat dari sejumlah penelitian tentang film yang mengambil berbagai topik seperti ; pengaruh film terhadap anak, film dan agresivitas, film dan politik, pengaruh film terhadap sex di masyarakat, dan lain sebagainya.

Karena film merupakan sarana penyampaian pesan yang dapat diterima dengan cepat, disamping itu isi film pada umumya tidak berbeda jauh dengan kehidupan sehari-hari. Dalam hal ini, agar pesan film dapat diterima oleh penontonnya dengan nyaman, penulis cerita sangat berperan penting dia harus dapat membuat alur cerita yang dapat membawa pemirsa hanyut dan menyelami isi ceritanya sesuai dengan yang diharapkan oleh penulis dan pemirsanya.

Dalam pesan yang disampaikan oleh penulis cerita akan dihasilkan makna yang dapat dipetik sehingga bermanfaat bagi pemirsanya. Karena secara tidak langsung setiap kegiatan yang dilakukan manusia dalam kehidupan sehari-harinya menyimpan sebuah makna. Dalam kajian ilmu pengetahuan makna memiliki rantai tersendiri yang dilambangkan melalui tanda. Sedangkan ilmu yang mengkaji tentang tanda itu sendiri adalah semiotika.

Secara umum film dibangun dengan banyak tanda, didalam tanda-tanda itu termasuk berbagai sistem tanda yang bekerja sama dengan baik dalam upaya mencapai efek yang diharapkan. Sistem semiotika yang lebih penting lagi dalam film adalah digunakannya tanda-tanda ikonis, yakni tanda-tanda yang menggunakan sesuatu ${ }^{16}$.

\section{Analisis Semiotika Dalam Film}

Kajian semiotika dalam film sudah banyak dilakukan diantaranya adalah Budi Irawanto seorang alumnus Unversitas Gadjah Mada, yang mengkaji semiotika atas teks film Enam Djam di Jogja, Janur Kuning dan Serangan Fajar. Ketiga film tersebut diproduksi pada masa yang berbeda oleh perusahaan film yang berbeda pula. Film Enam Djam di Jogja diproduksi pada masa Orde Lama, suatu periode yang sangat kuat diwarnai oleh persaingan ideologis antara kelompok sipil dan militer. Film ini diproduksi oleh Perfini (Perusahaan Film Nasional Indonesia) yang didirikan oleh Usmar Ismail pada tanggal 30 Maret 1950. Perfini pada mulanya berbentuk firma, kemudian berubah menjadi N.V, hari lahir Perfini inilah oleh Dewan Film Indonesia kemudian ditetapkan sebagai

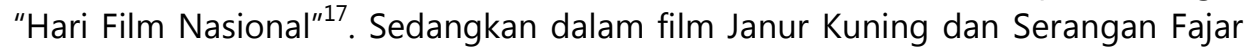
diproduksi masa Orde Baru, sebuah periode yang ditandai oleh dominannya peran kelompok militer yang ditopang oleh ideologi yang kuat. Janur Kuning

\footnotetext{
${ }^{16}$ Sobur, Op-cit, hal. 128

${ }^{17}$ Irwanto,Budi, Op-cit, hal. 6-7
}

Jurnal Ilmu Komunikasi, Vol. 1, No.1, April 2011

ISSN: 2088-981X 
diproduksi PT Metro 77 sebuah perusahaan film yang dimiliki oleh anggota senior polisi di Jakarta dan PT Karya Mandiri perusahaan film yang dimiliki Marsudi seorang kolonel yang memiliki hubungan dekat dengan Soeharto sejak perang kemerdekaan. Dan Marsudi pula yang bertanggung jawab terhadap bahan-bahan sejarah bagi film ini ${ }^{18}$. Adapun perusahaan yang mensponsori dan memproduksi Serangan Fajar adalah Pusat Produksi Film Negara (PPFN) yang dikepalai oleh Brigjen G.Dwipayana, yang telah lama menjadi staf pribadi Presiden Soeharto dan sekaligus menjadi penanggung jawab publikasi istana negara ${ }^{19}$.

Kesimpulan yang didapat dari film Enam Djam di Jogja, Janur Kuning dan Serangan Fajar mengguratkan dengan kuat peran perjuangan bersenjata dalam revolusi Indonesia 1945-1949. Ada upaya mengecilkan modus perjuangan diplomasi yang dilakukan kelompok politisi sipil. Karenanya, bisa dilihat dengan gamblang peran desisif kelompok militer daripada kelompok sipil selama berkecamuknya revolusi Indonesia ${ }^{20}$.

Secara relevan film merupakan bidang kajian bagi analisis semiotika, karena film dibangun dengan tanda semata-mata. Tanda-tanda itu termasuk berbagai sistem tanda yang bekerja sama dengan baik untuk mencapai efek bersamaan dengan tanda-tanda arsitektur, terutama indeksikal pada film digunakan tanda-tanda ikonis, yakni tanda-tanda yang menggambarkan sesuatu. $^{21}$

Sistem semiotika yang lebih penting dalam film digunakannya tandatanda ikonis, yakni berupa tanda-tanda yang dapat menggambarkan sesuatu yang dimaksud dalam penyampaian pesannya kepada audien. Metz dalam Sobur mengatakan meskipun ada upaya lain diluar pemikiran kontinental tentang des Hautes Etudes et Sciences Sociales (EHESS) Paris, merupakan figur utama dalam pemikiran semiotika sinematografi hingga sekarang ${ }^{22}$. Sumbangan Metz dalam teori film adalah usaha untuk menggunakan peralatan konseptual linguistik struktural untuk meninjau kembali teori film yang ada.

Salah satu area semiologi penting yang ditekuni Roland Barthes dalam studinya tentang tanda adalah peran pembaca (the reader). Konotasi, walaupun merupakan sifat asli tanda, membutuhkan keaktifan pembaca agar dapat berfungsi. Barthes secara panjang lebar mengulas apa yang sering disebut sebagai sistem pemaknaan tataran ke-dua, yang dibangun diatas sistem lain yang telah ada sebelumnya. Sistem ke-dua ini oleh Barthes disebut konotatif,

\footnotetext{
${ }^{18}$ Ibid, hal. 7

19 Ibid, hal. 7-8

20 Ibid, hal. 159

${ }^{21}$ Alex Sobur, Op-cit, hal. 128

22 Ibid, hal. 131
} 
yang didalam mythologies-nya secara tegas ia bedakan dari denotatif atau sistem pemaknaan tataran pertama. Barthes menciptakan peta tentang bagaimana tanda bekerja (Cobley \& Jansz, 199).

\section{Gambar peta tanda Roland Barthes ${ }^{23}$}

\begin{tabular}{|c|c|c|}
\hline $\begin{array}{c}\text { Signified } \\
\text { (penanda) }\end{array}$ & $\begin{array}{l}\text { 2. Signifer } \\
\text { (petanda) }\end{array}$ & \\
\hline \multicolumn{2}{|c|}{ 3. Denotative Sign (tanda denotative) } & \\
\hline \multicolumn{2}{|c|}{$\begin{array}{l}\text { 4. CONNNOTATIVE SIGNIFIER } \\
\text { (PENANDA KONOTATIF) }\end{array}$} & $\begin{array}{l}\text { 5. CONNOTATIVE SIGNIFIED } \\
\text { (PENANDA KONOTATIF) }\end{array}$ \\
\hline 6. $\mathrm{CO}$ & SIGN (TANDA & DTATIF) \\
\hline
\end{tabular}

Dari peta tersebut diatas terlihat jelas bahwa tanda denotatif (3) terdiri atas penanda (1) dan petanda (2). Akan tetapi pada saat bersamaan, tanda denotatif adalah juga penanda konotatif (4). Dengan kata lain, hal tersebut merupakan unsur material: hanya jika kita mengenal tanda "singa", barulah konotasi seperti harga diri, kegarangan, dan keberanian menjadi mungkin ${ }^{24}$. Dengan demikian sumbangan Barthes sangat berarti bagi penyempurnaan semiologi Saussure mengenai tanda konotatif tidak sekedar memiliki makna tambahan, namun juga mengandung kedua bagian tanda denotatif yang melandasi keberadaannya.

\section{Jenis-jenis film}

Dalam perkembangannya, baik karena kemajuan teknik-teknik yang semakin canggih maupun tuntutan massa penonton, pembuat film semakin bervariasi. Untuk sekedar memperlihatkan variasi film yang diproduksi, maka jenis-jenis film dapat digolongkan sebagai berikut:

1. Teatrical Film (Film teaterikal)

\footnotetext{
${ }^{23}$ Alex Sobur, Op-cit, hal. 123

${ }^{24}$ Ibid, hal. 69
} 
'Film teaterikal atau disebut juga film cerita, merupakan ungkapan cerita yang dimainkan oleh manusia dengan unsur dramatis dan memiliki unsur yang kuat terhadap emosi penonton. Pada dasarnya, film dengan unsur dramatis bertolak dari eksplorasi konflik dalam suatu kisah. Misalnya konflik manusia dengan dirinya sendiri,manusia dengan manusia yang lain,manusia dengan lingkungan sosialnya,yang pada intinya menunjukkan pertentangan, lewat plot kejadian-kejadian disampaikan secara visual. Cerita dengan unsur dramatis ini dijabarkan dengan berbagai tema.Lewat tema inilah film teaterikal digolongkan beberapa jenis yakni:

Pertama, Film Aksi (Action film), film ini bercirikan penonjolan filmnya dalam masalah fisik dalam konflik. Dapat dilihat dalam film yang mengeksploitasi peperangan atau pertarungan fisik,semacam film perang, silat, koboi, kepolisian, gengster dan semacamnya. Kedua, film Spikodrama, film ini didasarkan pada ketegangan yang dibangun dari kekacauan antara konflik-konflik kejiwaan,yang mengeksploitiasi karakter manusia,antara lain dapat dilihat dari film-film drama yang mengeksploitasi penyimpangan mental maupun dunia takhayul, semacam film horor. Ketiga, film komedi, film yang mengekspliotasi situasi yang dapat menimbulkan kelucuan pada penonton. Situasi lucu ini ada yang ditimbulkan oleh peristiwa fisik sehingga menjadi komedi. Selain itu,adapula kelucuan yang timbul harus diinterpretasikan dengan referensi intelektual. Keempat, film musik, jenis film ini tumbuh bersamaan dengan dikenalnya teknik suara dalam film, dengan sendirinya film jenis ini mengekspliotasi musik. Tetapi harus dibedakan antara film-film yang didalamnya terkandung musik dan nyanyian. Tidak setiap film dengan musik dapat digolongkan sebagai film musik. Yang dimaksud disini adalah film yang bersifat musikal, yang dicirikan oleh musik yang menjadi bagian internal cerita, bukan sekedar selingan.

2. Film Non-teaterikal (Non-teatrical film)

Secara sederhana,film jenis ini merupakan film yang diproduksi dengan memanfaatkan realitas asli, dan tidak bersifat fiktif. Selain itu juga tidak dikmaksudkan sebagai alat hiburan. Film-film jenis ini lebih cenderung untuk menjadi alat komunikasi untuk menyampaikan informasi (penerangan) maupun pendidikan. Film non-teaterikal dibagi dalam:

Pertama, film dokumenter, adalah istilah yang dipakai secara luas untuk memberi nama film yang sifatnya non-teaterikal. Bila dilihat dari subyek materinya film dokumenter berkaitan dengan aspek faktual dari kehidupan manusia, hewan dan makhluk hidup lainnya yang tidak dicampuri oleh unsur fiksi. Dalam konsepnya, film ini adalah drama ide yang dianggap dapat menimbulkan perubahan sosial. Karena bukan untuk kesenangan estetis, hiburan atau pendidikan. Tujuannya adalah untuk menyadarkan 
penonton akan berbagai aspek kenyataan hidup. Dengan kata lain,membangkitkan perasaan masyarakat atas suatu masalah,untuk memberikan ilham dalam bertindak, atau membina standart perilaku yang berbudaya. Dalam temanya berkaitan dengan apa yang terjadi atas diri manusia, berupa pernyataan yang membangkitkan keharuan dan kenyataan dalam kerangka kehidupan manusia.

Kedua, film pendidikan, film pendidikan dibuat bukan untuk massa, tetapi untuk sekelompok penonton yang dapat diidentifikasikan secara fisik. Film ini adalah untuk para siswa yang sudah tertentu bahan pelajaran yang akan diikutinya. Sehingga film pendidikan menjadi pelajaran ataupun instruksi belajar yang direkam dalam wujud visual. Isi yang disampaikan sesuai dengan kelompok penontonnya, dan dipertunjukkan di depan kelas. Setiap film ini tetap memerlukan adanya guru atau instruktur yang membimbing siswa.

Ketiga, film animasi, animasi kartun dibuat dengan menggambarkan setiap frame satu persatu untuk kemudian dipotret. Setiap gambar frame merupakan gambar dengan posisi yang berbeda yang kalau di-seri-kan akan menghasilkan kesan gerak. Pioner dalam bidang ini adalah Emile Cohl (1905), yang semula memfilmkan boneka kemudian membuat gambar kartun di Prancis. Sedang di Amerika Serikat Winsor McCay mempelopori film animasi (1909). Walt Disney menyempurnakan teknik dengan memproduksi seni animasi tikus-tikus, dan kemudian membuat film serita yang panjang seperti "Snow White and Seven Dwarfs" (1937) ${ }^{25}$.

Dengan menggunakan gambar, pembuat film dapat menciptakan gerak dan bentuk-bentuk yang tak terdapat dalam realitas. Apa saja yang dapat dipikirkan, dapat diflmkan melalui gambar. Dengan potensinya, film animasi tidak hanya digunakan untuk hiburan, tetapi juga untuk illustrasi dalam film pendidikan. Misalnya dengan gambar grafis yang bersifat dinamis ataupun kerja mesin ataupun skema yang hidup.

Dengan menggunakan gambar, pembuat film dapat menciptakan gerak dan bentuk-bentuk yang tak terdapat dalam realitas. Apa saja yang dapat dipikirkan, dapat pula difilmkan melalui gambar. Dengan potensinya, film animasi tidak hanya untuk hiburan, tetapi juga untuk ilustrasi dalam film pendidikan. Misalnya dengan gambar grafis yang bersifat dinamis, ataupun cara kerja mesin ataupun skema yang hidup.

Film kemudian diklasifikasikan sebagai berikut:

- "G" (General)

: film untuk semua umur

${ }^{25}$ M. Sumarno, Dasar-Dasar Apresiasi Film, (Jakarta: PT Gramedia Widiasarana Indonesia, 1996), hal. 16-17 
- "PG" (Parental Guidance) : film yang dianjurkan didampingi orang tua

- "PG-13"

- " $\mathrm{R}$ " (Restriced)

- " $X "$
: film dibawah 13 th dan didampingi orang tua

: film dibawah 17 th,didampingi orang dewasa

: film untuk 17 th keatas.

\section{Fungsi dan Pengaruh Film}

Fungsi dan pengaruh film sepanjang sejarah perkembangannya telah banyak mengalami perubahan. Selama lebih dari sepertiga abad ini, film sebagaimana radio, merupakan sumber hiburan yang murah. Karena sedemikian pentingnya bagi masyarakat imigran film merupakan media sosialisasi utama bagi mereka. Mereka pergi ke "sekolah-malam" untuk mempelajari dasar-dasar bahasa Inggris dan kewarganegaraan, tetapi pelajaran itu dilaksanakan seperti di rumah sendiri sebagai mana mereka mendengar radio. Mereka mempelajari bagaimana seharusnya seorang Amerika berbicara dan bertingkah laku, dan aspirasi mereka ditingkatkan dengan pameran kekayaan atau kemakmuran di layar film.

Fungsi film telah banyak mengalami perubahan secara substansial sebagaimana perubahan pada audience-nya. Film-film yang ditonton kalangan imigran dewasa ini, terutama yang diputar di kota-kota besar,pada umumnya berasal dari dari negara asal mereka serta memakai dialek asli mereka. Dengan demikian film tidak lagi berfungsi sebagai sarana sosialisasi di kalangan mereka sendiri,tapi lebih dari itu film dapat membantu mereka untuk tetap menjaga keterikatan mereka terhadap tanah kelahiran serta kebudayaannya. Film-film Hollywood dewasa ini membuat film untuk kalangan berusia belasan sampai dua puluh tahunan, selain melayani kebutuhan sosial mereka, film telah memberikan kepada mereka tempat kemana sebaiknya pergi untuk berbincangbincang dengan teman-teman. Untuk mereka yang setengah baya, film dapat berfungsi sebagai salah satu sarana pergaulan, suatu tempat kencan.

Film sebagai bentuk tontonan memiliki waktu putar tertentu, rata-rata satu setengah jam sampai dengan dua jam, selain itu film tidak hanya menjanjikan pengalaman yang mengasikkan, melainkan pengalaman hidup sehari-hari yang dikemas secara menarik. Sedangkan alasan khusus mengapa orang menyukai film adalah karena adanya usaha manusia untuk mencari hiburan dan meluangkan waktu. Film yang menyajikan gambar hidup telah memikat khalayak sehingga mereka bersedia duduk berlama-lama di depan layar, karena bagi khalayak menonton film dapat dijadikan untuk pemahaman nilai-nilai baru dengan melihat hal-hal yang telah terjadi didunia. Alasan lain khalayak penonton film adalah menjadikan film sebagai pelepas ketegangan 
dari realitas nyata yang dihadapinya dan merupakan tempat pelarian dari beban hidup sehari-hari.

Marselli Sumarno menyebut fungsi film memiliki nilai pendidikan. Nilai pendidikan sebuah film tidak sama dengan kata pendidikan di bangku sekolah atau kuliah. Nilai pendidikan sebuah film mempunyai makna sebagai pesanpesan moral film yang semakin halus pembuatannya akan semakin baik. Pesan pendidikan di sebuah film bila dibuat dengan halus akan menimbulkan kesan bahwa khalayak tidak merasa digurui. Hampir semua film mengajari atau memberi tahu khalayak tentang sesuatu, karena dengan menonton film khalayak dapat belajar bagaimana bergaul dengan orang lain, bertingkah laku, berpenampilan dan sebagainya ${ }^{26}$.

Film cerita yang dibuat dengan tujuan komersial sekalipun biasanya memberikan pesan moral yang terselip di dalamnya. Film cerita action yang sarat dengan adegan kekerasan sekalipun juga mengandung suatu makna atau pesan moral tertentu. Film diproduksi tidak mungkin tanpa tujuan tertentu, walaupun film-film yang beredar di pasaran bersifat komersial, tetapi tidak dapat dipungkiri bahwa peranannya begitu penting dalam kehidupan.

Fungsi persuasif suatu film dapat dilihat dari kandungan pesan yang berusaha untuk mengendalikan sikap atau perilaku penontonnya. Berbeda dengan fungsi hiburan dari film yang hanya menyampaikan hal-hal menyenangkan, dalam pengertian hanya untuk memenuhi kepuasan batin.

Beberapa fungsi film yang diproduksi dan dieksebisikan sering kita temui misalnya ; fungsi informasional dapat ditemukan pada film berita (newsreel), fungsi instruksional dapat dilihat dalam film pendidikan, fungsi persuasif terkandung dalam film dokumenter, sedangkan fungsi hiburan dapat ditemukan pada jenis film cerita. Perlu diketahui dan diingat bahwasanya setiap film selalu mengandung unsur hiburan. Film informasional, instruksional, maupun persuasif selain mengandung pesan yang memungkinkan terlaksananya fungsi juga harus memberikan kesenangan atau hiburan kepada khalayak. Marselli Sumarno menambahkan bahwa film selain memiliki empat fungsi tersebut diatas juga memiliki suatu nilai artistic. Nilai artistic sebuah film dapat terwujud bila nilai keartistikannya ditemukan pada seluruh unsurnya ${ }^{27}$.

\footnotetext{
${ }^{26}$ Ibid, hal. 96

27 Ibid, hal. 97
} 


\section{Penutup}

Film berdasarkan kajian semiotik sanagatlah urgen dan menarik, karena perkembangan dan pertumbuhan film begitu pesat dan mampu menggerakkan khalayak sebagai penonton. Hasil kajian akan dijadikan dasar penilaian apakah film tersebut layak ditonton atau sebaliknya. Suatu film sebaiknya dinilai dari segi artistic bukan secara rasional saja, sebab jika hanya dinilai secara rasional, sebuah film artistic boleh jadi tidak berharga karena tidak mempunyai maksud dan makna tertentu.

\section{Daftar Pustaka}

Sobur, Alex 2003, Semiotika Komunikasi, PT Remaja Rosydakarya, Bandung.

Irwanto, Budi 1999, Film, Ideologi, dan Militer; Hegemoni Militer dalam Sinema Indonesia, Media Pressindo, Yogyakarta.

Kurniawan 2001, Semiologi Roland Barthes, Yayasan Indonesiatera, Magelang.

Sumarno, M 1996, Dasar-Dasar Apresiasi Film, PT Gramedia Widiasarana Indonesia, Jakarta..

Effendi, Onong Uchjana 1996, Ilmu, Teori dan Filsafat Komunikasi, Citra Adidtya, Bandung.

Cobley, Paul \& Jansz, Litza 1999, Introducing Semiotic. Totem Books. New York.

W Littlejohn, Stephen 1996, Theories of Human Communication, Five Edition, Wadsworth Publishing Company Albuquerqu, New Mexico,. 